\title{
Recovery of the immune system in diabetic mice after transplantation of isolated islets of Langerhans
}

\author{
M. Hadžija, M. Slijepčević, V. Šverko, T. Marotti, and M. Poljak-Blaži \\ Ruder Bošković Institute, Zagreb, Yugoslavia
}

\begin{abstract}
Summary. Adult CBA/HZgb mice islets harvested by collagenase digestion were injected intraperitoneally in 52 singeneic diabetic recipients ( $\mathrm{CBA} / \mathrm{HZgb} \rightarrow \mathrm{CBA} / \mathrm{HZgb}, 450-600$ islets per mouse). Normal serum glucose levels, 24-h urine volume, insulin levels and body weight were completely restored to normal in all recipients during the next $2-5$ months. Immunological function was assessed in control, diabetic and diabetic-transplanted mice by following their responses to sheep erythrocytes (expressed as the number plaque-forming cells in the spleen). In transplanted mice, the plaque-forming cell responses were as follows: 1 month after transplantation
\end{abstract}

$-43 \%$ of the plaque-forming cell counts in control (normal, non-diabetic) mice; 2 months after transplantation $-56 \%$ of the control value; and $94 \%$ of the control value after 5 months. Ten months after the transplantation, the plaque-forming cell counts were slightly above the control value (148\%). It appears, therefore that transplantated islet tissue positively affects the immunological as well as the diabetic state of the recipients.

Key words: Islet transplantation, immune system, experimental diabetes, pancreatic islet isolation.
Bacterial and mycotic infections are common in diabetes mellitus [1]. Such infections are difficult to eradicate, and complicate management of the diabetic state. $\mathrm{Nu}$ merous investigators have reported that the susceptibility of diabetic patients to infections should be ascribed to defects of polymorphonuclear leucocytes [2,3]. Other investigators noted decreased numbers of T- and B-lymphocytes in peripheral blood and a depression of lymphocytic response to phytohaemagglutinin, suggesting impaired cell-mediated immunity in diabetic patients [4-6]. In a rat model, Mahmoud et al. [7] also found suppression of cell-mediated immunity. Pavelić et al. [8] described a decreased number of nuclear cells in thymus and spleen of alloxan diabetic mice. Brown et al. [9] and our group [10] described decreased antibody production to sheep red blood cells, a T-cell dependent antigen $[9,10]$. Rejection of skin allografts was delayed in animals with experimental diabetes $[8,11]$. According to our determination of $\mathrm{E}, \mathrm{E}_{37}$ or $\mathrm{EAC}$ rosettes in spleens of diabetic mice [12], defect of immunological function appears to be due not only to metabolic disturbances, but possibly also to altered proportions of the subpopulations of T and B cells. Daily injections of insulin into animals with experimental diabetes only partly restored the immunological function. This response was dependent on duration of the disease [13]. In this report we compare reversal of the diabetic state in mice after transplantation of isolated adult islets from syngeneic donors with recovery of their immunological system.

\section{Materials and methods}

\section{Animals and induction of experimental diabetes}

Female CBA/HZgb mice, aged 2 and 4 months, were used as donors or recipients of isolated pancreatic tissue. Recipients were made diabetic by intravenous injection of alloxan $(50 \mathrm{mg} / \mathrm{kg}$ body weight, Sigma, monohydrate, Lot. 50F-3823), prepared in phosphate-buffered saline (Hank's) solution. The drug was injected 14 days before planned transplantation. Mice received food and water ad libitum both before and after injection of the drug.

Blood glucose was determined by the method of Hyvarinen and Nikkilä, as modified by our laboratory [14]. Test-Tape strips (Gluketur-Test, Pliva, Zagreb) were used to check glycosuria. Only mice with glycosuria of $>28 \mathrm{mmol} / 1$ were considered diabetic and were used in the experiment.

\section{Isolation of islets of Langerhans}

Islets of Langerhans were isolated from adult mice, aged 2 months, by the collagenase method of Lacy and Kostianovsky [16]. Following perfusion and distention of pancreatic tissue with $10 \mathrm{ml}$ of cold $\left(4^{\circ} \mathrm{C}\right)$ Hank's solution containing $0.68 \%$ neutral red, aprotinin (Trasylol, 500 units $/ \mathrm{ml}$, Sigma), the pancreas was excised, chopped into fine pieces with scissors, and digested in Hank's solution containing col- 


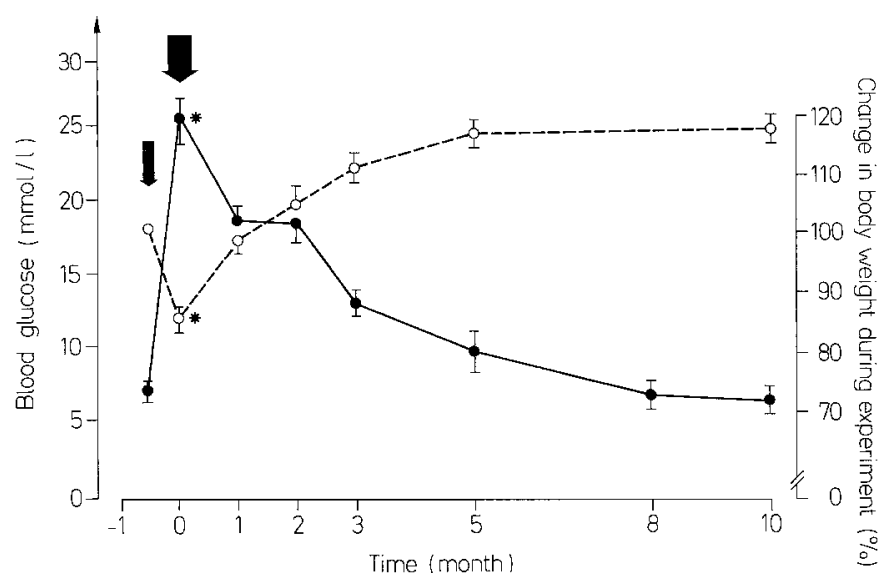

Fig. 1. The metabolic response to transplantation of isolated islets of Langerhans. Blood glucose $(-\bullet)$ and body weight $\left(\mathrm{O}-\mathrm{-O-}^{-} \mathrm{O}\right)$ during a 10-month post-transplantation period. 1 : injection of alloxan; transplantation of isolated islets of Langerhans. $p<0.001$

lagenase $(10 \mathrm{mg} / \mathrm{ml}$, Sigma $)$, bovine serum albumin $(10 \mathrm{mg} / \mathrm{ml}$, Sig$\mathrm{ma})$, and Hepes ( $20 \mathrm{mmol} / 1$, Sigma). This was carried out within $12-17 \mathrm{~min}$ in a shaker bath at $36.5^{\circ}-37^{\circ} \mathrm{C}$, operating at $95 \mathrm{cycles} / \mathrm{min}$. Cold $\left(4^{\circ} \mathrm{C}\right)$ Hank's solution $(50 \mathrm{ml})$ was then added. Fragments were further dispersed manually by repeated aspiration ( $40-55$ times) with a siliconized Pasteur pipette, washed, and centrifuged at $200 \mathrm{~g}$ for 2 min. Sedimented tissue was dispersed with Hank's solution and free islets of Langerhans were collected by means of a Pasteur pipette under stereo microscope (Opton) at magnification $\times 20$. Suspension of isolated islets was inoculated intraperitoneally, 450-600 islets per mouse.

\section{Assay of plaque-forming cells}

Washed sheep red blood cells $\left(2 \times 10^{8}\right.$ in $\left.0.5 \mathrm{ml}\right)$ were injected intravenously. After 4 days plaque-forming cells were counted in the spleen, the haemolytic plaque test of Jerne et al. [15] as carried out in our laboratory [17].

\section{Results}

\section{Effect of islet transplantation on recovery from the diabetic state}

In diabetic mice body weight decreased rapidly (Fig. 1), the volume of urine increased to as high as $28.2 \pm$ $3.6 \mathrm{ml} /$ day (compared with $0.33 \mathrm{ml} /$ day in normal nondiabetic mice), and the concentration of insulin in plasma (radioimmunoassay test) decreased to $8.0 \pm$ $1.3 \mathrm{mU} / 1$ (compared with $12.9 \pm 0.4 \mathrm{mU} / 1$ in normal mice). Transplantation of islets resulted in rapid recovery of body weight (Fig.1), decrease of urine volume to normal values within $2-5$ months after transplantation, and restoration of insulin secretion. Two months after islets transplantation, plasma insulin was higher than in control mice $(15.1 \pm 0.22 \mathrm{mU} / 1 ; p<0.025)$.

In diabetic mice there was evident impairment of immune response (Table 1). Transplantation of the islets resulted in recovery of immune competence: 2 months after transplantation, the mean plaque-forming cell

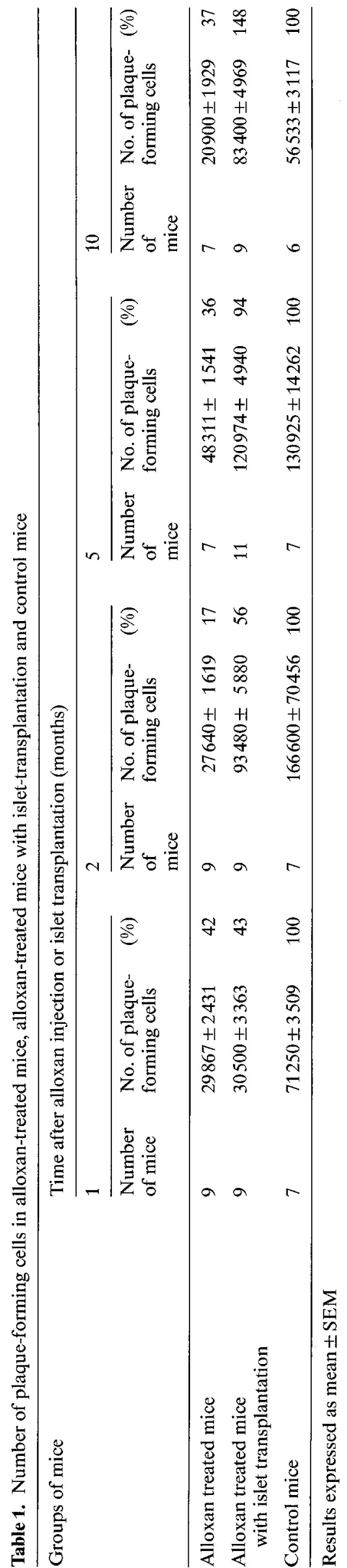


count was $56 \%$ of that in control non-diabetic mice; at 5 months, it approached the control value $(96 \%)$, and at 10 months it was even increased in islet recipients $(48 \%$ above control value).

\section{Discussion}

Alloxan exerts a highly specific cytotoxic effect on the $\beta$ cells of mouse pancreatic islets, and the resulting clinical condition closely resembles human insulin-dependent diabetes mellitus. In this model, using syngeneic mice and transplanting isolated islets, we demonstrated recovery of body weight, normalisation of glucose level in blood, disappearance of glycosuria, and rise of insulin concentration in serum.

The immune response to bacterial antigens is reduced in diabetic patients $[2,3,5]$. In addition to the correction of metabolic derangement, islet transplantation also resulted in recovery of immune competence. Treatment with insulin corrects metabolic status but the immune competence is only partly restored [14]. This may indicate that the immune system requires a full complement of islet hormones for its proper function, and that impairment reflects not only metabolic, but also a hormonal defect.

\section{References}

1. Younger D, Hadley BW (1971) Infection in diabetes. In: Morbile A, White P, Bradley RF, Krall LP (eds) Joslins diabetes mellitus, Lea \& Febiger, Philadelphia, pp 621-636

2. Nolan CM, Beaty HN, Bagdade JD (1978) Further characterization of the impaired bacterial function of granulocytes in patients with poorly controlled diabetes. Diabetes 27:889-894

3. Cech P, Stalder H, Widman JJ, Rohner A, Miescher PA (1979) Leukocyte myeloperoxidase deficiency and diabetes mellitus associated with candida albicans liver abscess. Am J Med 66: $149-153$

4. Cattaneo R, Saibene V, Pozza G (1976) Peripheral T-lymphocytes in juvenile-onset diabetes (JOD) and in maturnity-onset diabetics (MOD). Diabetes 25: 223-226

5. Kadrnka-Lovrenčić M, Rabatić S, Mažuran R, Oberiter V, Dekaris D (1979) Cell mediated immunity in children with juvenile onset diabetes mellitus. Period Biol 81: 255-256

6. Selam JL, Glot J, Mirouze J (1979) Circulating lymphocyte subpopulations in juvenile insulin-dependent diabetes. Correction of abnormalities by adequate blood glucose control. Diabetologia $16: 35 \div 40$

7. Mahmoud AF, Rodman HM, Mandel MA, Warren KS (1976) Induced and spontaneous diabetes mellitus and suppression of cellmediated immunologic responses: granuloma formation, delayed dermal reactivity, and allograft rejection. J Clin Invest 57:362-367

8. Pavelić K, Slijepčević M, Pavelić J (1978) Recovery of immune system in diabetic mice after treatment with insulin. Horm Metab Res 10: 381-386

9. Brown DM, Yunis EJ, Fernandes G (1977) T-cell function in diabetic mice. Fed Porc 36: 1258 (Abstract)

10. Maduna S, Slijepčević M, Hadžija M, Stanković V (1980) Immunological reactivity in diabetes mellitus-analysis of differences among various forms immunologic response. Diab Croat 9 : $61-74$

11. Friedman EA, Beyer MM (1977) Immune competence of the streptozotocin-induced diabetic rats. I. Absent second-set skin allograft response. Transplantation 24: 367-371

12. Hadžija M, Benković B, Slijepčević M (1979) Effect of insulin and of the oral antidiabetic drugs Euglucon and Glurenorm on the immunological functions of diabetic mice. Period Biol 81: 185-186

13. Slijepčević M, Hadžija M, Stanković V (1979) Long lasting experimental diabetes and immunological response in mice. Period Biol 81: 183-184

14. Slijepčević M, Radačić M (1976) The growth of a transplantable leukemia in normal and alloxan treated mice. Period Biol 78: $130-132$

15. Jerne NK, Nordin RA, Henry O (1963) The agar plaque technique for recognizing antibody forming cells. In: Amos B, Koprowski $\mathrm{H}$ (eds) Cell bound antibodies. Wister Institute Press, Philadelphia, pp 109-122

16. Lacy PE, Kostianovsky M (1967) Method for the isolation of intact islets of Langerhans from the rat pancreas. Diabetes 16:35-39

17. Hršak I, Marotti T (1973) Immunosuppression mediated by Erlich ascites fluid. Eur J Cancer 9: 717-724

Dr. M. Hadžija

'Ruder Bošković' Institute

Bijenička c. 54

YU-41000 Zagreb

Yugoslavia 